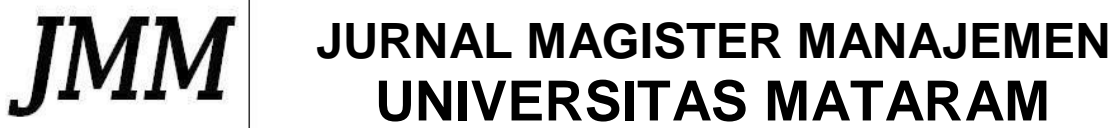 \\ UNRAM VOL. 6 No. 1 MARET 2017
}

\section{PENGARUH PERTUMBUHAN EKONOMI, UKURAN PEMERINTAH DAERAH, DAN PENDAPATAN ASLI DAERAH TERHADAP KELEMAHAN SISTEM PENGENDALIAN INTERN (STUDI PADA PEMERINTAH KABUPATEN/KOTA DI INDONESIA)}

\author{
Abdul Majid 1 \\ Hj. Rr.Titiek Herwanti ${ }^{2}$ \\ Nur Fitriah ${ }^{3}$
}

\begin{abstract}
The purposed of the study was to test the influence of economic growth, the local size government and local revenue to internal control system weakness of local government. The thesis is associative research. The population in this thesis are all regency / city in Indonesia and the scope of the discussion was about the influence of economic growth, the local size goverment, and local revenues, in cases of weakness of internal control systems in 2013. The samples were determined by using purposive sampling by total amount of the datas were 229, the total samples obtained 146 districts and cities in Indonesia by Slovin sampling formula. Data obtained through the Result of BPK's Summary In 2014, The APBD's Realization Statement, Balance Sheet Regions obtained from the website of the Directorate General of Fiscal Balance, the Finance Ministry of Republic Indonesia and APBD's Realization Statement which was obtained from Respective of Regional Revenue each district/city government and the regional balance provided report of the asset which was a measure of local governments and economic growth through the BPS's data. The results of this study showed the economic growth was positive influance in internal control system weakness, local size governments was negative influance in internal control syistem weakness, and the local revenues was positive influance in internal control system weakness but its unsignificant.
\end{abstract}

Keywords : internal control system weakness, economic growth, local size government, and local revenues.

\section{PENDAHULUAN}

Berjalannya otonomi daerah di Indonesia memerlukan pengawasan dan pengendalian yang memadai agar tidak terjadi kecurangan (fraud). Kecurangan (fraud) yang terjadi dalam sebuah organisasi baik organisasi sektor publik maupun sektor swasta biasanya disebabkan oleh lemahnya pengendalian intern. Berdasarkan KPMG Fraud Survey 2012 yang dilakukan di Australia dan New Zealand menemukan bahwa lemahnya pengendalian intern menjadi faktor utama penyebab terjadinya kecurangan yaitu sebesar $28 \%$ dari total kasus kecurangan yang terjadi (KPMG, 2012). Kondisi ini menunjukkan betapa pentingnya kita mengupas masalah sistem pengendalian intern dalam rangka menekan terjadinya kasus-kasus fraud.

Selanjutnya berdasarkan hasil pemeriksaan Badan Pemeriksa Keuangan (BPK) atas Laporan Keuangan Pemerintah Daerah (LKPD) Tahun 2012 (IHP Semester I dan II Tahun

2013) terhadap 494 LKPD, terdapat 6.406 kasus atau rata-rata 13 kasus kelemahan SPI per kabupaten/kota. Sedangkan untuk LKPD Tahun 2013 (IHP Semester I Tahun 2014) Badan Pemeriksa Keuangan (BPK) menemukan jumlah kelemahan SPI 6.531 kasus terhadap 428 LKPD atau rata-rata 15 kasus per kabupaten/kota. Meningkatnya rata-rata jumlah

\footnotetext{
${ }^{1}$ Mahasiswa Program Magister Akuntansi Pascasarjana Universitas Mataram

${ }^{2}$ Dosen Pembimbing Utama Program Magister Akuntansi Pascasarjana Universitas Mataram

${ }^{3}$ Dosen Pembimbing Pendamping Program Magister Akuntansi Pascasarjana Universitas Mataram
} 


\section{TMM JURNAL MAGISTER MANAJEMEN UNIVERSITAS MATARAM

temuan/kasus yang terkait kelemahan pengendalian intern tentu tidak sejalan dengan tekad pemerintah yang ingin mewujudkan suatu pemerintahan yang bersih dan akuntabel

Salah satu faktor yang dianggap mempengaruhi kelemahan sistem pengendalian intern adalah pertumbuhan ekonomi. Daerah kabupaten/kota yang mengalami pertumbuhan ekonomi tinggi biasanya ditopang dengan berkembangnya investasi modal swasta dan pemerintah serta berkembangnya aktivitas ekonomi masyarakat, yang tentunya harus diawali dengan pengalokasian belanja pemerintah yang tepat, sistem birokrasi yang handal dan regulasi yang mendukung iklim investasi. Pemerintah daerah yang mengejar pertumbuhan ekonomi juga berani mengambil risiko (risk taker) untuk mengalokasikan anggaran pemerintah pada sektor-sektor produktif dan dalam pengambilan kebijakannya cenderung mengabaikan sistem pengendalian intern. Argumen ini didukung dengan penelitian yang dilakukan Martani dan Zaelani (2011), yang menemukan bahwa pertumbuhan ekonomi memiliki hubungan positif dengan kelemahan pengendalian intern. Doyle et al. (2007) mengungkapkan bahwa perusahaan yang sedang banyak perubahan dalam operasi termasuk cenderung memiliki masalah dalam pengendalian intern. Ashbaugh-Skipe et al. (2006) menemukan bahwa pertumbuhan perusahaan memiliki pengaruh positif terhadap masalah pengendalian intern. Penelitian Petrovits et al. (2010) menyimpulkan bahwa masalah pengendalian intern berhubungan positif dengan organisasi nirlaba yang sedang tumbuh. Sementara penelitian Hartono dkk. (2014) menemukan pertumbuhan ekonomi berpengaruh negatif terhadap kelemahan pengendalian intern. Dan Nirmala dan Daljono (2013) menemukan pertumbuhan BUMN tidak memiliki pengaruh signifikan terhadap kelemahan pengendalian internal. Selain pertumbuhan ekonomi, size (ukuran) juga mempengaruhi kelemahan sistem pengendalian intern.

Ukuran pemerintah kabupaten/kota oleh Dirjen Perimbangan Keuangan-Departemen Keuangan RI, dalam hal ini diproksikan dengan nilai Total Asset akan memberikan gambaran ukuran yang beragam untuk masing-masing pemerintah kabupaten/kota. Dengan rata-rata Total Asset senilai Rp.3,60 triliyun untuk masing-masing pemerintah kabupaten/kota pada Tahun 2013, Aset Tetap menempati proporsi yang dominan, yaitu sebesar $91,74 \%$

Pendapatan Asli Daerah (PAD) juga mempengaruhi kelemahan sistem pengendalian intern pemerintah daerah. Walaupun proporsi PAD dalam pembentukan Pendapatan Daerah masih tergolong rendah, khususnya untuk pemerintah kabupaten/kota di Indonesia yang pada Tahun 2013 rata-rata sebesar 11,40\%, potensi PAD tetap menjadi lahan basah untuk terjadinya fraud (kecurangan). Pemerintah daerah yang memiliki sumber-sumber PAD yang besar dan beragam akan membutuhkan sistem pengendalian intern yang lebih kompleks untuk dapat mengamankan sumber-sumber PAD-nya dibanding daerah-daerah yang miskin sumber PAD.

Rumusan masalah dalam penelitian ini adalah: 1) apakah pertumbuhan ekonomi berpengaruh terhadap kelemahan sistem pengendalian intern?; 2) apakah ukuran pemerintah daerah berpengaruh terhadap kelemahan sistem pengendalian intern?; 3) apakah pendapatan asli daerah berpengaruh terhadap kelemahan sistem pengendalian intern?; dan apakah pertumbuhan ekonomi, ukuran pemerintah daerah dan pendapatan asli daerah berpengaruh terhadap kelemahan sistem pengendalian intern?.

Sesuai dengan rumusan masalah yang dikemukakan di atas, penelitian ini bertujuan untuk mengetahui apakah pertumbuhan ekonomi, ukuran pemerintah daerah, dan pendapatan asli daerah berpengaruh terhadap kelemahan sistem pengendalian intern baik secara parsial maupun secara simultan. 


\section{TMM JURNAL MAGISTER MANAJEMEN UNIVERSITAS MATARAM UNRAM VOL. 6 No. 1 MARET 2017}

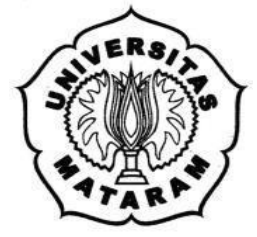

Penelitian ini diharapkan dapat memberikan kontribusi terhadap pengembangan literatur Akuntansi Sektor Publik (ASP) terutama pada masalah sistim pengadilan intern, laju perkembangan ekonomi dan otonomi daerah yang selanjutnya dapat dijadikan sebagai acuan bagi penelitian lain. Hasil penelitian ini juga diharapkan dapat memberikan gambaran dan sumbangan konseptual bagi penelitian selanjutnya tentang perkembangan kondisi pemerintah di Indonesia dan fenomena yang muncul di dalamnya. Selain itu, penelitian ini juga dapat digunakan sebagai bahan referensi serta masukan lebih lanjut tentang masalah pengendalian intern pemerintah daerah sehingga dapat mewujudkan tata kelola pemerintahan yang baik (good governance) dalam usaha menciptakan kesejahteraan bagi masyarakat.

\section{TINJAUAN PUSTAKA}

Teori Keagenan (Agency Theory), menurut Scott (1997) adalah hubungan atau kontrak antara principal dan agent, dimana principal adalah pihak yang mempekerjakan agent agar melakukan tugas untuk kepentingan principal, sedangkan agent adalah pihak yang menjalankan kepentingan principal. Menurut Jensen dan Meckling (1976), hubungan keagenan adalah sebagai kontrak, dimana satu atau beberapa orang (principal) mempekerjakan orang lain (agent) untuk melaksanakan sejumlah jasa dan mendelegasikan wewenang untuk mengambil keputusan kepada agent tersebut.

Dalam hubungan keagenan antara eksekutif dan legislatif, eksekutif sebagai agent dan legislatif sebagai prinsipal (Halim \& Abdullah, 2006). Johnson (1994) kemudian menyebut hubungan eksekutif/birokrasi dengan legislatif/kongres dengan sebutan self-interest model. Legislator ingin dipilih kembali, birokrat ingin memaksimumkan anggarannya, dan konstituen ingin memaksimumkan utilitasnya. Untuk dapat terpilih kembali, legislator (orang yang menjalankan fungsi legislatif) mencari program dan kegiatan yang membuatnya populer di mata konstituen. Birokrat (orang yang menjalankan fugsi birokrasi di pemerintahan) mengusulkan program-program baru agar agency-nya dapat berkembang dan konstituen dapat terus percaya mereka telah menerima manfaat (benefit) dari pemerintah. Menurut Elgie and Jones (2000), legislatif dapat juga berperilaku moral hazard dalam merealisasikan self-interestnya. Lalu dinyatakan oleh Colombatto (2001) bahwa adanya discretionary power (akibat pendelegasian wewenang Principal ke Agent) akan menimbulkan pelanggaran atas kontrak keagenan, dan karenanya dapat diprediksi bahwa semakin besar discretionary power yang dimiliki legislatif semakin besar pula kecenderungan mereka mengutamakan kepentingan pribadinya.

Agency Theory menyatakan bahwa konflik antara principal dan agent disebabkan adanya perbedaan informasi antara principal dan agent. Keadaan asimetri informasi terjadi ketika adanya distribusi informasi yang tidak sama antara principal dan agent (Fama dan Jensen, 1983), sehingga agent atau Pemerintah Daerah melakukan kecurangan (fraud) dalam pelaporan keuangan Pemerintah Daerah. Untuk mengurangi terjadinya kecurangan maka perlu dilaksanakan pengendalian intern Pemerintah Daerah yang baik.

Sistem Pengendalian Intern adalah sebuah entitas yang terdiri dari bagian-bagian yang saling berinteraksi yang dikoordinasikan untuk mencapai satu atau lebih tujuan bersama (Wilkinson, et al., 2000). Sementara Mulyadi (2001) mengemukakan bahwa pada

dasarnya sistem adalah sekelompok elemen yang erat berhubungan satu dengan yang lainnya, yang berfungsi bersama-sama untuk mencapai tujuan tertentu.

Kelemahan Sistem Pengendalian Intern, jumlah kasus terkait kelemahan pengendalian intern diperoleh dari hasil audit Badan Pemeriksa Keuangan (BPK) terhadap 


\section{TMM JURNAL MAGISTER MANAJEMEN UNIVERSITAS MATARAM UNRAM VOL. 6 No. 1 MARET 2017}

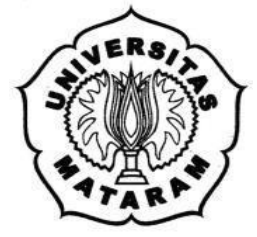

Laporan Keuangan Pemerintah Daerah (LKPD) Tahun 2013 di seluruh Indonesia. Kelemahan pengendalian intern tersebut didapatkan dengan melihat tingkat kesesuaian pengendalian intern terhadap standar audit yang telah ditetapkan yaitu Standar Pemeriksaan Keuangan Negara.

Pertumbuhan Ekonomi, seringkali dibedakan dengan pembangunan ekonomi. Pertumbuhan ekonomi adalah proses kenaikan output perkapita diproksi dengan Produk Domestik Regional Bruto (PDRB) perkapita (Boediono,1985). Satu-satunya ukuran yang paling penting dalam konsep ekonomi adalah produk domestik bruto (PDB) yang mengukur total nilai barang dan jasa yang dihasilkan pada suatu negara atau nasional dan PDRB untuk mengukur total nilai barang dan jasa yang dihasilkan pada suatu daerah atau lokal. PDB digunakan untuk banyak tujuan tetapi yang paling penting adalah untuk mengukur ke seluruh performa dari suatu perekonomian (Samuelson, 2004).

Ukuran Pemerintah Daerah, menurut Ferry dan Jones dalam Panjaitan (2004), tolok ukur yang bisa dijadikan dasar untuk menunjukkan besar kecilnya perusahaan antara lain: total penjualan, rata-rata tingkat penjualan, dan total aktiva. Perusahaan yang tergolong dalam ukuran besar umumnya memiliki jumlah aset atau total aktiva yang besar pula, sehingga dapat menarik investor untuk menanamkan modalnya pada perusahaan tersebut.

Pendapatan Asli Daerah, menurut Abdullah dan Halim (2004:67), "Pendapatan Asli Daerah (PAD) merupakan semua penerimaan daerah yang berasal dari sumber ekonomi asli daerah. Pasal 157 UU No. 32 Tahun 2004 dan Pasal 6 UU No. 33 Tahun 2004 menjelaskan bahwa sumber Pendapatan Asli Daerah terdiri: 1) Pajak Daerah; 2) Retribusi Daerah; 3) Hasil pengelolaan kekayaan daerah yang dipisahkan; 4) Lain-lain Pendapatan Asli Daerah (PAD) yang sah.

Menurut Undang-Undang No. 33 Tahun 2004, Pasal 1, .Pendapatan Asli Daerah adalah penerimaan yang diperoleh daerah dari sumber-sumber di dalam daerahnya sendiri yang dipungut berdasarkan peraturan daerah sesuai dengan peraturan perundang-undangan yang berlaku. Pendapatan Asli Daerah merupakan sumber penerimaan daerah yang asli digali di daerah yang digunakan untuk modal dasar pemerintah daerah dalam membiayai pembangunan dan usaha-usaha daerah untuk memperkecil ketergantungan dana dari pemerintah pusat.

Menurut Mardiasmo (2002:132), Pendapatan Asli Daerah adalah penerimaan daerah dari sektor pajak daerah, retribusi daerah, hasil perusahaan milik daerah, hasil pengelolaan kekayaan daerah yang dipisahkan, dan lain-lain Pendapatan Asli Daerah yang sah. Semakin besarnya nilai dan beragamnya sumber-sumber Pendapatan Asli Daerah tentu membutuhkan langkah-langkah pengendalian yang semakin kompleks agar tidak terjadi kebocoran.

\section{Rerangka Konseptual}

Kelemahan pengendalian intern merupakan kelemahan yang signifikan yang hasilnya jauh dari kondisi salah saji material pada laporan keuangan tahunan yang tidak dapat dicegah atau dideteksi. Adanya indikator untuk mengetahui tingkat kasus kelemahan pengendalian intern menjadikan Pemerintah Daerah untuk lebih memperhatikan kualitas pengendalian internalnya. Berdasarkan landasan teori dan hasil-hasil penelitian terdahulu, dapat diidentifikasi faktor-faktor yang mempengaruhi kelemahan pengendalian intern sebagai hasil audit BPK atas Laporan Keuangan Pemerintah Daerah antara lain :

pertumbuhan ekonomi daerah, ukuran pemerintah daerah, dan pendapatan asli daerah. Oleh karena itu, guna mempermudah jalan pemikiran terhadap permasalahan yang dibahas, disusunlah rerangka konseptual penelitian dengan gambaran sebagai berikut : 


\section{$\int M M \quad \begin{gathered}\text { JURNAL MAGISTER MANAJEMEN } \\ \text { UNIVERSITAS MATARAM }\end{gathered}$ UNRAM VOL. 6 No. 1 MARET 2017}

Gambar2.1 Rerangka Konseptual

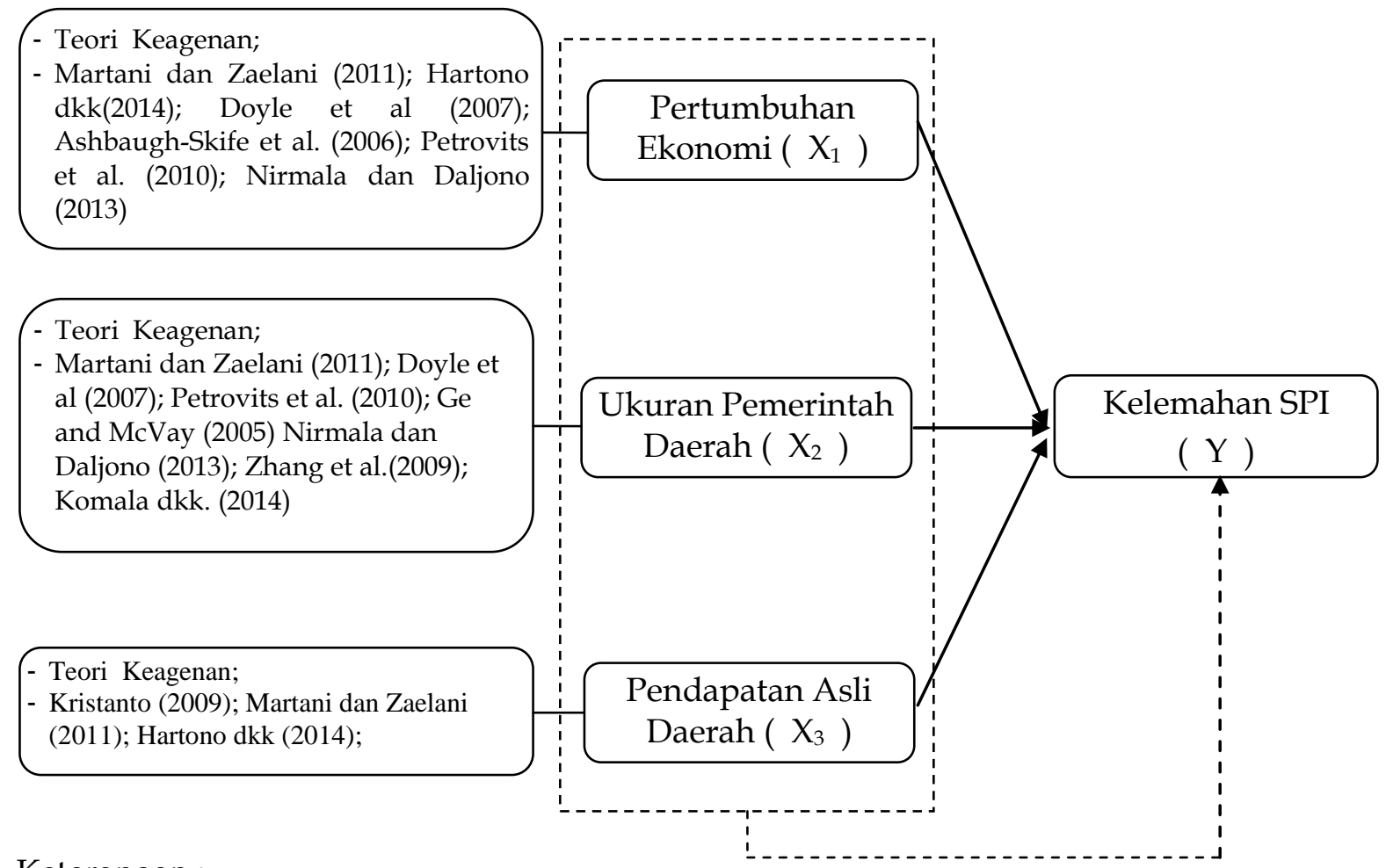

Keterangan :

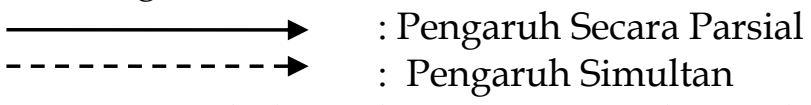

Pertumbuhan ekonomi merupakan salah satu tujuan penting yang ingin dicapai pemerintah daerah. Hal ini mengingat peran pemerintah daerah selaku agen yang diberikan mandat oleh principal (DPRD, masyarakat dan stakeholder lainnya) untuk meningkatkan kesejahteraan masyarakat yang tentunya dilakukan melalui gerakan pembangunan ekonomi. Untuk mendukung pembangunan ekonomi, pemerintah daerah tentu akan mengkonsentrasikan anggaran pemerintah daerah pada pos-pos belanja daerah yang mendukung terciptanya pertumbuhan ekonomi. Selaku agen yang baik, yang bertanggungjawab atas kesejahteraan masyarakatnya, pemerintah daerah akan mengejar pertumbuhan ekonomi yang tinggi dan cenderung mengabaikan sistem pengendalian internnya. Penelitian Martani dan Zaelani (2011), menemukan bahwa pertumbuhan ekonomi memiliki hubungan positif dengan kelemahan pengendalian intern. Penelitian Doyle et al. (2007) mengungkap bahwa perusahaan yang sedang banyak perubahan dalam operasi termasuk cenderung memiliki masalah dalam pengendalian intern. Penelitian AshbaughSkipe et al. (2006) menemukan bahwa pertumbuhan perusahaan memiliki pengaruh positif terhadap masalah pengendalian intern. Penelitian Petrovits et al. (2010) menyimpulkan bahwa masalah pengendalian intern berhubungan positif dengan organisasi nirlaba yang sedang tumbuh.

Atas dasar uraian diatas dapat dikemukakan hipotesis awal yang menggambarkan pengaruh pertumbuhan ekonomi terhadap kelemahan sistem pengendalian intern sebagai berikut:

$H_{1}$ : Pertumbuhan Ekonomi berpengaruh postif terhadap kelemahan sistem pengendalian intern. 


\section{TMM JURNAL MAGISTER MANAJEMEN UNIVERSITAS MATARAM UNRAM VOL. 6 No. 1 MARET 2017}

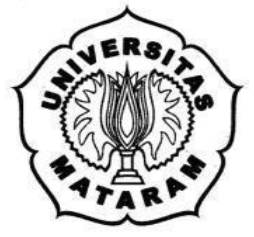

Size (ukuran) Pemerintah Daerah dapat menunjukkan besar kecilnya keadaan Pemerintah Daerah. Banyaknya jumlah aset yang dimiliki mendorong pemerintah daerah untuk mengimplementasikan praktik-praktik sistem pengendalian intern yang baik sebagai pertanggungjawaban pemerintah daerah selaku agent yang diberikan wewenang oleh principal (DPRD, masyarakat, dan stakeholder lainnya) untuk menjaga keutuhan aset-aset publik (aset daerah) yang berada dalam pengawasannya. Sehingga selaku agen yang baik yang akan menjaga keutuhan aset-aset daerah, pemerintah daerah akan cenderung meningkatkan sistem pengendalian internnya. Kristanto (2009) menemukan pengaruh positif ukuran pemerintahan terhadap kelemahan pengendalian intern. Sementara Martani dan Zaelani (2011) dan Hartono dkk. (2014), menemukan adanya pengaruh yang negatif antara ukuran pemerintahan daerah terhadap kelemahan pengendalian internal. Doyle et al. (2007) menyebut bahwa kelemahan pengendalian intern secara keseluruhan dimiliki oleh perusahaan yang lebih kecil.

Atas dasar uraian di atas dapat dikemukakan hipotesis awal yang menggambarkan pengaruh ukuran pemerintah daerah terhadap kasus kelemahan sistem pengendalian intern sebagai berikut :

$\mathrm{H}_{2}$ : Ukuran Pemerintah Daerah berpengaruh negatif terhadap kelemahan sistem pengendalian intern.

Pendapatan Asli Daerah (PAD) merupakan penerimaan bagi daerah dalam rangka melaksanakan otonomi daerah. Pemungutannya berdasarkan peraturan dan UndangUndang yang berlaku. Besar kecilnya Pendapatan Asli Daerah (PAD) dapat menggambarkan daerah yang sudah bisa mengelola potensi dari daerahnya masing-masing. Proporsi PAD juga dapat menjadi gambaran kemandirian keuangan daerah. Principal tentu berkepentingan untuk mendorong pemerintah daerah selaku agen untuk terus meningkatkan kemandirian daerah. Dan selaku agent yang baik pemerintah daerah akan mengkonsentrasikan sumberdaya daerah untuk terus meningkatkan perburuan terhadap sumber-sumber PAD. Dan dalam kondisi seperti ini pemerintah daerah cenderung mengabaikan sistem pengendalian internnya. Martini dan Zaelani (2011) menemukan pendapatan asli daerah berpengaruh positif terhadap kelemahan pengendalian internal. Petrovits et al. (2010) menemukan bahwa masalah pengendalian intern pada organisasi nirlaba memiliki hubungan positif dengan kondisi keuangan lemah. Doyle et al. (2007) menyimpulkan bahwa perusahaan yang memiliki banyak kelemahan pengendalian intern cenderung lemah secara keuangan.

Atas dasar uraian di atas dapat dikemukakan hipotesis awal yang menggambarkan pengaruh pendapatan asli daerah terhadap kasus kelemahan sistem pengendalian intern sebagai berikut :

$\mathrm{H}_{3}$ : Pendapatan Asli Daerah Berpengaruh positif terhadap Kelemahan Sistem Pengendalian Intern.

Sebagai agen yang baik yang berkewajiban meningkatkan kesejahteraan masyarakat pemerintah daerah akan mengkonsentrasikan sumberdaya daerah untuk meningkatkan pertumbuhan ekonomi dan cenderung mengabaikan sistem pengendalian internnya. Dan untuk terus meningkatkan kemandirian daerah, pemerintah daerah cenderung mengkonsentrasikan sumberdaya daerah untuk perburuan sumber-sumber PAD sehingga cenderung mengabaikan sistem pengendalian internnya. Sementara untuk menjaga keutuhan aset daerah yang berada dalam pengawasannya maka pemerintah daerah akan

berusaha untuk menciptakan sistem pengendalian intern yang memadai. Walaupun ketiga variabel bebas ini akan memberikan pengaruh yang berlawanan arah, ketinganya tetap memberikan pengaruh terhadap kelemahan sistem pengendalian intern. Hartono dkk. (2014) menyimpulkan bahwa variabel pertumbuhan, size, PAD dan kompleksitas secara 


\section{TMM JURNAL MAGISTER MANAJEMEN UNIVERSITAS MATARAM

simultan berpengaruh terhadap kelemahan pengendalian intern. Dan Kristanto (2009) menyimpulkan bahwa ukuran pemerintahan, pendapatan asli daerah, dan belanja modal secara bersama-sama signifikan mempengaruhi kelemahan pengendalian intern

Dengan demikian untuk menggambarkan hubungan secara simultan ketiga variabel bebas diatas terhadap kasus Kelemahan Sistem Pengendalian Intern dapat dirumuskan hipotesis sebagai berikut:

$H_{4}$ : Pertumbuhan Ekonomi, Ukuran Pemerintah Daerah, dan Pendapatan Asli Daerah Berpengaruh terhadap Kelemahan Pengendalian Intern.

\section{METODE PENELITIAN}

Penelitian ini merupakan penelitian asosiatif, yaitu penelitian yang bertujuan untuk mengetahui hubungan antara dua variabel atau lebih (Sugiyono, 2013:37). Penelitian ini dilakukan dengan mengambil lokasi seluruh daerah Kabupaten/Kota di Indonesia dengan ruang lingkup pembahasan mengenai pengaruh pertumbuhan ekonomi, ukuran daerah, dan pendapatan asli daerah, terhadap kasus kelemahan sistem pengendalian intern pada tahun 2013.

Populasi dari penelitian ini adalah seluruh daerah kabupaten/kota di Indonesia yang berjumlah 508 buah, sedangkan pengambilan sample pada penelitian ini menggunakan (purposive sampling), yakni pengambilan sample berdasarkan beberapa kriteria yang ditentukan: Daerah kabupaten/kota di Indonesia yang dijadikan obyek Audit Keuangan (LKPD) tahun 2013 oleh BPK yang hasil auditnya dipublikasikan melalui Ihtisar Hasil Pemeriksaan Tahun 2014, kecuali yang mendapat opini disclaimer dan adversed untuk menjaga validitas nilai variabel Ukuran Pemerintah Daerah (yang diproksikan dengan total aset) serta nilai varibel Pendapatan Asli Daerah Memiliki informasi variabel-variabel yang diukur, serta didalamnya memuat satuan pemahaman pengendalian internal, termasuk laporan kepatuhan terhadap undang-undang dan Pengendalian Internal. Berdasarkan kriteria di atas, bebearapa daerah kabupaten/kota yang memenuhi criteria tersebut sehingga dapat ditentukan jumlah populasi sample dalam penelitian ini adalah 229 kabupaten/kota Setelah mengetahui jumlah populasi nyata yang layak untuk dijadikan sampel penelitian, jumlah sampel ditentukan menggunakan rumus Slovin sehingga ditemukan jumlah sampel ideal untuk penelitian ini adalah sebanyak 146 Kabupaten/Kota.

Variabel memberikan gambaran yang lebih nyata mengenai fenomena-fenomena yang digeneralisasikan dalam konstruk. Variabel-variabel dalam penelitian ini dapat dikelompokkan ke dalam variabel bebas (independen) dan variabel terikat (dependen).Variabel bebas adalah variabel yang mempengaruhi variabel terikat, entah secara positif atau negatif (Sekaran, 2006). Variabel bebas dalam penelitian ini adalah pertumbuhan ekonomi, ukuran pemerintah daerah, dan pendapatan asli daerah. Variabel terikat adalah variabel yang dipengaruhi oleh variabel bebas (Indriantoro dan Supomo, 2002). Variabel terikat dalam penelitian ini adalah kelemahan sistem pengendalian intern.

Data yang digunakan dalam penelitian ini adalah data sekunder, bersumber dari: 1) Ihtisar Hasil Pemeriksaan BPK Tahun 2014 yang memuat ikhtisar jumlah kasus kelemahan sistem pengendalian intern masing-masing pemerintah kabupaten/kota; 2) Laporan Realisasi APBD dan Neraca Daerah yang diperoleh dari website Direktorat Jenderal

Perimbangan Keuangan Kementerian Keuangan Republik Indonesia melalui www.djpk.depkeu.go.id. Dari laporan realisasi APBD ini diperoleh data Pendapatan Asli Daerah masing-masing Pemerintah Kabupaten/Kota dan dari Neraca Daerah memberikan 


\section{TMM JURNAL MAGISTER MANAJEMEN UNIVERSITAS MATARAM UNRAM VOL. 6 No. 1 MARET 2017}

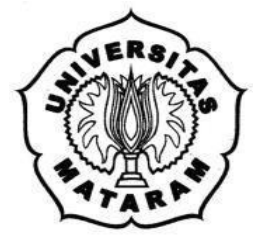

data Aset Daerah sebagai ukuran pemerintah daerah; dan 3) data Pertumbuhan Ekonomi yang bersumber dari data BPS melalui www.bps.go.id.

\section{Prosedur Analisis Data}

Data dianalisis dengan menggunakan metode analisa data multivariate, yang merupakan metode statistik deskriptif dan inferensial yang digunakan untuk menganalisa data lebih dari dua variabel penelitian.

\section{Uji Asumsi Klasik}

Sebelum dilakukan pengujian hipotesis dengan menggunakan analisis regresi maka diperlukan pengujian asumsi klasik meliputi:

1. Uji Normalitas, bertujuan untuk mengetahui distribusi data dalam variabel yang digunakan dalam penelitian. Data yang baik dan layak digunakan dalam penelitian adalah data yang memiliki distribusi normal (Nugroho, 2005: 18). Untuk menguji apakah distribusi normal atau tidak dapat dilihat melalui normal probability plot dengan membandingkan distribusi kumulatif dan distribusi normal. Data normal akan membentuk satu garis lurus diagonal, dan ploting data akan dibandingkan dengan garis diagonal. Jika distribusi data adalah normal, maka garis yang menggambarkan data sesungguhnya akan mengikuti garis diagonalnya

(Ghozali, 2013: 110).

2. Uji Multikolinieritas, diperlukan untuk mengetahui ada tidaknya variabel independen yang memiliki kemiripan dengan variabel independen lain dalam satu model (Nugroho, 2005: 58). Selain itu deteksi terhadap multikoliniearitas juga bertujuan untuk menghindari bias dalam proses pengambilan keputusan mengenai pengaruh pada uji parsial masing-masing variabel independen terhadap variabel dependen. Deteksi multikolinieritas pada suatu model dapat dilihat jika nilai Variance Inflation Factor (VIF) tidak lebih dari 10 dan nilai Tolerance tidak kurang dari 0,1, maka model tersebut dapat dikatakan terbebas dari multikolinieritas. VIF $=1 /$ Tolerance, jika VIF $=10$ maka Tolerance $=1 / 10=0,1$. (Nugroho, 2005)

\section{Model Pengujian Hipotesis}

Pengujian hipotesis dilakukan dengan menggunakan model analisis regresi berganda bertujuan untuk memprediksi kekuatan pengaruh seberapa variabel independen terhadap variabel dependen (Sekaran, 1992). Dalam penelitian ini digunakan tingkat signifikansi (a) 0,05 atau $5 \%$. Untuk menguji apakah hipotesis yang diajukan diterima atau ditolak, maka dilakukan pengujian terhadap variabelvariabel penelitian dengan cara menguji secara simultan melalui signifikansi simultan (Uji statistik F), yang bermaksud untuk dapat menjelaskan pengaruh variabel independen terhadap variabel dependen. Sedangkan untuk menguji masing-masing variabel secara parsial, dilakukan dengan uji signifikansi parameter individual (uji $\mathrm{t}$ statistik) yang bertujuan untuk mengetahui apakah variabel independen berpengaruh atau tidak terhadap variabel dependen, serta variabel mana yang dominan mempengaruhi variabel dependen. Pengujian dilakukan dengan persamaan regresi sebagai berikut:

\begin{tabular}{|c|c|}
\hline $\begin{array}{l}\text { KSPI = } \\
\text { dimana: }\end{array}$ & ${ }_{1} \mathrm{PE}+\beta_{2} \mathrm{UPD}+\beta_{3} \mathrm{PAD}+\mathrm{e}$ \\
\hline KSP & $=$ Kelemahan Sistem Pengendalian Intern \\
\hline a & $=$ Konstanta \\
\hline$\beta_{1} \beta_{2} \beta_{3}$ & $=$ Slope atau Koefisien Regresi \\
\hline PE & $=$ Pertumbuhan Ekonomi \\
\hline UPD & $=$ Ukuran Pemerintah Daerah \\
\hline PAD & $=$ Pendapatan Asli Daerah \\
\hline e & $=$ Error Term \\
\hline
\end{tabular}




\section{TMM JURNAL MAGISTER MANAJEMEN UNIVERSITAS MATARAM UNRAM VOL. 6 No. 1 MARET 2017}

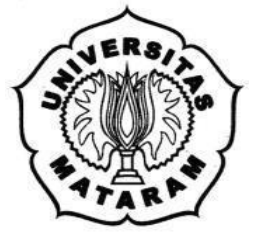

Pengujian hipotesis dalam penelitian ini dilakukan secara parsial (uji t) dan pengujian secara simultan (uji F) serta uji koefisien determinasi $\left(R^{2}\right)$.

Uji Signifikansi Parameter Individual (Uji Statistik t)

Uji statistik $\mathrm{t}$ pada dasarnya menunjukkan seberapa jauh pengaruh satu variabel independen secara individual menerangkan variabel dependen (Ghozali, 2013:98). Uji t dapat dilakukan dengan melihat nilai probabilitas signifikansi $t$ masing-masing variabel yang terdapat pada output hasil regresi. Jika nilai probabilitas signifikansi t lebih kecil dari 0,05 maka dapat dikatakan bahwa ada pengaruh yang kuat antara variabel independen dengan variabel dependen. Dalam hal ini digunakan untuk menguji signifikansi pengaruh variabel pertumbuhan ekonomi, ukuran pemerintah daerah, dan pendapatan asli daerah terhadap kelemahan sistem pengendalian intern.

Untuk keperluan pengujian, dirumuskan hipotesis statistik sebagai beirkut :

$\mathrm{H}_{0} 1$ : Sig. $>0,05$ : Tidak terdapat pengaruh Pertumbuhan Ekonomi terhadap Kelemahan Sistem Pengendalian Intern.

Ha1 : Sig. $\leq 0,05$ : Pertumbuhan Ekonomi berpengaruh terhadap Kelemahan Sistem Pengendalian Intern.

$\mathrm{H}_{0} 2$ : Sig. $<0,05$ : Tidak terdapat pengaruh Ukuran Pemerintahan Daerah terhadap Kelemahan Sistem Pengendalian Intern.

Ha2 : Sig. $\geq 0,05$ : Ukuran Pemerintahan Daerah berpengaruh terhadap Kelemahan Sistem Pengendalian Intern.

$\mathrm{H}_{0} 3$ : Sig. $>0,05$ : Tidak terdapat pengaruh Pendapatan Asli Daerah terhadap Kelemahan Sistem Pengendalian Intern.

Ha3 : Sig. $\leq 0,05$ : Pendapatan Asli Daerah berpengaruh terhadap Kelemahan Sistem Pengendalian Intern.

Uji Signifikansi Simultan (Uji Statistik F)

Uji statistik $\mathrm{F}$ pada dasarnya menunujukkan apakah semua variabel independen atau bebas yang dimasukkan dalam model mempunyai pengaruh secara bersama-sama terhadap variabel dependen/terikat (Ghozali, 2013:98). Dalam uji F digunakan ketentuan sebagai berikut:

a) Apabila probabilitas signifikansi $>0,05$ dan $\mathrm{F}$ hitung $<\mathrm{F}_{\text {tabel }}$ maka Ho ditolak dan Ha diterima.

b) Apabila probablitas signifikansi $<0,05$ dan $\mathrm{F}$ hitung $>\mathrm{F}_{\text {tabel }}$ maka Ho diterima dan Ha ditolak.

Untuk keperluan pengujian, dirumuskan hipotesis statistik sebagai berikut:

$\mathrm{H}_{0} 4: \mathrm{a}<0,05$ dan $\mathrm{F}$ hitung $>\mathrm{F}$ tabel : Tidak ada pengaruh simultan Pertumbuhan Ekonomi, Ukuran Pemerintahan Daerah, dan Pendapatan Asli Daerah terhadap Kelemahan Sistem Pengendalian Intern.

$\mathrm{H}_{0} 4: \mathrm{a}>0,05$ dan $\mathrm{F}$ hitung $<\mathrm{F}$ tabel : Pertumbuhan Ekonomi, Ukuran Pemerintahan Daerah, dan Pendapatan Asli Daerah secara simultan berpengaruh terhadap Kelemahan Sistem Pengendalian Intern 


\section{JMM JUMNAL UNRAM VOL. 6 No. 1 MARET 2017}

\section{Analisis Koefisien Determinasi $\left(\mathbf{R}^{2}\right)$}

Koefisien determinasi $\left(\mathrm{R}^{2}\right)$ pada intinya mengukur seberapa jauh kemampuan model dalam menerangkan variasi variabel dependen. Nilai koefisien determinasi adalah antara nol dan satu. Nilai $\mathrm{R}^{2}$ yang kecil menunjukkan kemampuan variabel-variabel independen dalam menjelaskan variasi variabel dependen yang terbatas. Nilai yang mendekati satu berarti variabel independen memberikan hampir semua informasi yang dibutuhkan untuk memprediksi variabel dependen (Ghozali, 2013:97)

\section{Hasil Penelitian}

\section{HASIL PENELITIAN DAN PEMBAHASAN}

Populasi dalam penelitian ini adalah Pemerintah Daerah yang ada di Indonesia. Sampel Pemerintah Daerah yang berhasil diperoleh dalam penelitian ini sebanyak 229 Pemerintah Daerah dengan total data 508 Pemerintah Daerah. Data yang digunakan dalam penelitian ini diperoleh dari Badan Pusat Statistika (BPS) dan Badan Pemeriksa Keuangan (BPK) pada tahun 2014. Fokus penelitian ini adalah ingin melihat pengaruh tingkat pertumbuhan ekonomi, ukuran pemerintahan daerah, dan Pendapatan Asli Daerah (PAD) terhadap kelemahan pengadilan intern pada Pemerintah Daerah. Proses seleksi sampel berdasarkan kriteria yang telah ditetapkan dan ditampilkan dalam tabel berikut ini:

Tabel 4.1

Penentuan Sampel

\begin{tabular}{|c|c|}
\hline Kriteria & Jumlah \\
\hline - Jumlah pemerintah kabupaten/kota di Indonesia & 508 \\
\hline - Kabupaten/kota yang tidak dijadikan obyek audit LKPD Tahun 2014 & $(17)$ \\
\hline - Kabupaten/kota yang mendapat opini adversed/disclaimer & $(53)$ \\
\hline $\begin{array}{l}\text { - Kabupaten/kota yang tidak memiliki informasi lengkap terkait } \\
\text { variabel yang diukur }\end{array}$ & (209) \\
\hline Jumlah populasi $(\mathrm{N})$ nyata & 229 \\
\hline $\begin{array}{l}\text { Pengambilan sampel dengan rumus Slovin dengan } \mathrm{e}=0,05 \\
\left(\mathrm{n}=\frac{N}{1+N \cdot e^{2}}\right)=\frac{229}{1+229(0,05)^{2}}=145,63 \quad \text { (dibulatkan menjadi 146) }\end{array}$ & 146 \\
\hline
\end{tabular}

Sumber: Data sekunder yang diolah

Data dianalisis dengan menggunakan metode analisa data multivariate, yang merupakan metode statistik deskriptif dan inferensial yang digunakan untuk menganalisa data lebih dari dua variabel penelitian, sementara untuk pengujian hipotesis dengan menggunakan analisis regresi. Tujuannya adalah untuk memperoleh gambaran yang menyeluruh mengenai pengaruh pertumbuhan ekonomi, Pendapatan Asli Daerah (PAD) dan ukuran pemerintah daerah terhadap pengendalian intern pada Pemerintah Daerah.

Hipotesis dalam penelitian ini diuji dengan menggunakan model regresi berganda (multiple regression). Tujuannya adalah untuk memperoleh gambaran yang menyeluruh mengenai pengaruh pertumbuhan ekonomi, Pendapatan Asli Daerah (PAD) dan ukuran pemerintah daerah terhadap pengendalian intern pada Pemerintah Daerah.

\section{Hasil Uji Statistik Deskriptif}

Untuk mendapatkan gambaran umum tentang sampel data yang menjadi bahan uji dalam penelitian ini, pada tabel 4.2 berikut disajikan hasil run uji statistik deskriptif. 


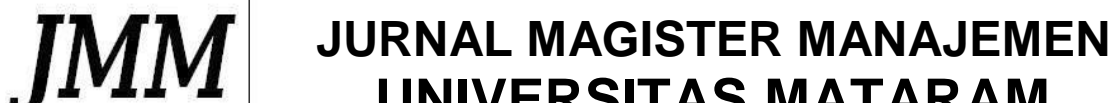 UNIVERSITAS MATARAM UNRAM VOL. 6 No. 1 MARET 2017}

Tabel 4.2

Hasil Statistik Deskriptif

Descriptive Statistics

\begin{tabular}{|l|r|r|r|r|r|}
\hline & $\mathrm{N}$ & \multicolumn{1}{|c|}{ Mean } & Std. Deviation & Minimum & Maximum \\
\hline KELEMAHAN_SPI & 146 & 11.01370 & 4.97923 & 2.00 & 23.00 \\
Ln_TOTAL_ASSET & 146 & 28.32398 & .45691 & 27.23 & 29.91 \\
Ln_PAD & 146 & 24.73319 & .86415 & 23.06 & 27.13 \\
PERTUMBUHAN_EKONOMI & 146 & 6.21815 & 1.13556 & 2.41 & 10.09 \\
\hline
\end{tabular}

Sumber : Data sekunder tahun 2013, diolah dengan SPSS 16

Berdasarkan Tabel 4.2 diatas, hasil analisis data menggunakan statistik deskriptif terhadap 146 pemerintah kabupaten/kota tahun 2013 memberikan gambaran masingmasing variabel sebagai berikut: Variabel kelemahan sistem pengendalian intern memiliki nilai minimum sebanyak 2 temuan, yaitu pada Kabupaten Landak di Provinsi Kalimantan Barat, dan nilai maksimum sebanyak 23 temuan yaitu pada Kabupaten Enrekang dan Kabupaten Sinjai di Provinsi Sulawesi Selatan, dengan rata-rata 11 temuan dan standar deviasi 4,97. Kabupaten Landak yang memiliki temuan kelemahan sistem pengendalian intern paling rendah (2 temuan), memiliki nilai pertumbuhan ekonomi sebesar 6,21\% (atau di bawah rata-rata sebesar 6,22\%), ukuran pemerintah daerah (Ln Total Asset) sebesar 28,54 (di atas rata-rata sebesar 28.32) dan pendapatan asli daerah (ln PAD) sebesar 24,25 (di bawah rata-rata sebesar 24,74). Sedangkan Kabupaten Enrekang yang memiliki temuan kelemahan sistim pengendalian intern paling tinggi (23 temuan), memiliki nilai pertumbuhan eonomi sebesar 6,96\% (di atas rata-rata 6,22\%), ukuran pemerintah daerah (Ln Total Asset) sebesar 27,98 (di bawah rata-rata sebesar 28.32) dan pendapatan asli daerah (In PAD) sebesar 23,87 (di bawah rata-rata sebesar 24,74).

Data riil pada Kabupaten Landak dan Kabupaten Enrekang di atas memberikan gambaran bahwa temuan kelemahan sistem pengendalian intern cenderung rendah pada daerah kabupaten/kota yang memiliki pertumbuhan ekonomi rendah (di bawah rata-rata) dan ukuran pemerintah daerah yang kecil (nilai Total Asset di atas rat-rata), dan temuan kelemahan sistem pengendalian intern cenderung tinggi pada daerah kabupaten/kota yang memiliki pertumbuhan ekonomi tinggi (di atas rata-rata) dan ukuran pemerintah daerah yang besar (nilai Total Asset di bawah rata-rata) .

Variabel pertumbuhan ekonomi memiliki nilai minimum sebesar 2,41\%, yaitu pada Kabupaten Cilacap, dan nilai maksimum sebesar 10,09\%, yaitu pada Kabupaten Jayapura, dengan rata-rata 6,22\% dan standar deviasi 1,14. Kabupaten Cilacap yang memiliki nilai pertumbuhan ekonomi paling rendah di antara 146 kabupaten/kota sampel tahun 2013, memperoleh temuan kelemahan sistim pengendalian intern sebanyak 14 temuan (diatas rata-rata 11 temuan). Sedangkan Kabupaten Jayapura yang memiliki pertumbuhan ekonomi paling tinggi di antara 146 kabupaten/kota sampel tahun 2013, memperoleh temuan kelemahan sistim pengendalian intern sebanyak 19 temuan (diatas rata-rata 11 temuan).

Variabel ukuran pemerintah daerah yang diproksikan dengan nilai total asset memiliki nilai minimum sebesar 27,23 atau Rp.669.862.000.000,00, yaitu pada Kabupaten Pidie Jaya di Provinsi Aceh Darussalam dan nilai maksimum sebesar 29,91 atau Rp.9.722.884.000.000,00 yaitu pada Kota Samarinda di Provinsi Kalimantan Timur, dengan rata-rata 28,32 dan standar deviasi 0,46. Kabupaten Pidie Jaya yang merupakan pemerintah daerah dengan ukuran paling kecil di antara 146 kabupaten/kota sampel tahun 2013, memperoleh temuan kelemahan sistem pengendalian intern sebanyak 13 temuan (di atas rata-rata 11 temuan). Sedangkan Kota Samarinda yang merupakan pemerintah daerah 


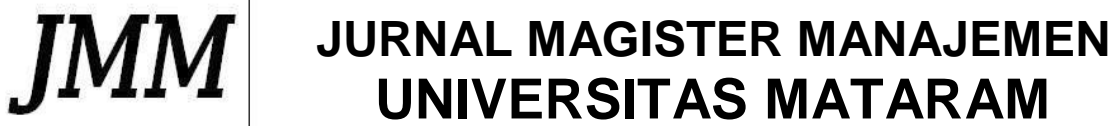 UNRAM VOL. 6 No. 1 MARET 2017}

dengan ukuran paling besar memperoleh temuan kelemahan sistim pengendalian intern sebanyak 9 temuan (di bawah rata-rata 11 temuan). Gambaran pada kedua daerah ini mengindikasikan bahwa semakin besar ukuran pemerintah daerah di lihat dari total assetnya, semakin rendah temuan kelemahan sistem pengendalian internnya.

Variabel pendapatan asli daerah memiliki nilai minimum 23,06 atau Rp.10.346.000.000,00, yaitu pada Kabupaten Tulang Bawang Barat dan nilai maksimum sebesar 27,13 atau Rp. 606.340.000.000,00 yaitu pada Kota Batam, dengan rata-rata 24,73 dan standar deviasi 0,86. Kabupaten Tulang Bawang Barat yang memiliki pendapatan asli daerah paling rendah di antara 146 kabupaten/kota sampel tahun 2013, memperoleh temuan kelemahan sistim pengendalian intern sebanyak 10 temuan (di bawah rata-rata sebesar 11 temuan). Sedangkan Kota Batam yang memiliki pendapatan asli daerah paling tinggi, memperoleh temuan kelemahan sistim pengendalian intern sebanyak 11 temuan (sama dengan rata-rata).

\section{Hasil Uji Asumsi Klasik}

Tahapan dalam pengujian regresi berganda menggunakan beberapa uji asumsi klasik yang harus dipenuhi meliputi: uji normalitas, uji multikolinearitas dan uji heterokedastisitas yang secara rinci dijelaskan sebagai berikut:

\section{a. Hasil Uji Normalitas}

Hipotesis dalam penelitian ini dengan menggunakan model regresi berganda (multiple regression). Tujuanya adalah untuk memperoleh gambaran yang menyeluruh mengenai pengaruh variabel independen (tingkat pertumbuhan ekonomi, Pendapatan Asli daerah (PAD) dan Ukuran pemerintah daerah) terhadap variabel dependen (kelemahan pengendalian intern). Berikut ini disajikan hasil uji normalitas yang dapat dilihat pada gambar 4.4 di halaman berikutnya. Selengkapnya mengenai hasil uji normalitas penelitian dapat dilihat pada gambar 4.1 sebagai berikut.

Gambar 4.1 Hasil Uji Normalitas

\section{Normal P-P Plot Of Regrezion Standardized Residual}

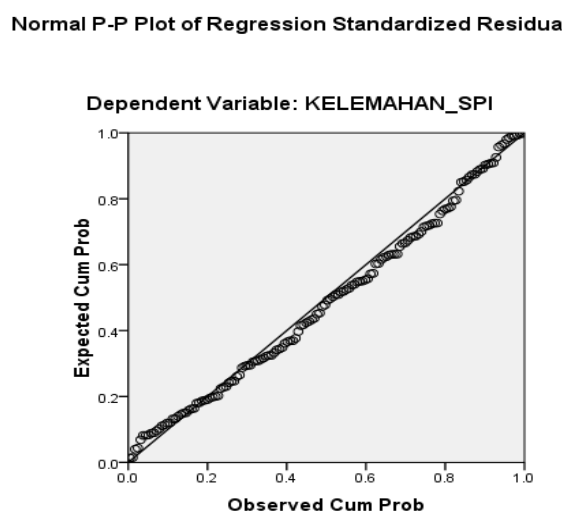

Gambar 4.1 Normal Probability Plot 


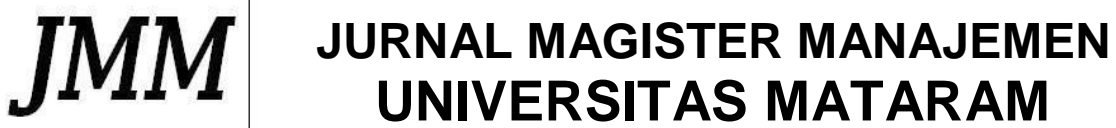 UNRAM VOL. 6 No. 1 MARET 2017}

Pada gambar 4.1 di atas tampak jelas distribusi data membentuk garis lurus mengikuti garis diagonal, sehingga dapat disimpulkan bahwa data yang digunakan berdistribusi normal.

\section{b. Uji Multikolinieritas}

Model regresi yang baik adalah regresi dengan tidak adanya gejala korelasi yang kuat di antara variabel bebasnya. Berikut ini disajikan hasil. Hasil uji multikolinearitas yang dapat dilihat pada tabel 4.3 sebagai berikut:

Tabel 4.3.

Hasil Uji Multikolinearitas

\begin{tabular}{|l|r|r|}
\hline \multirow{2}{*}{ Model } & \multicolumn{2}{|c|}{ Collinearity Statistics } \\
\cline { 2 - 3 } \multicolumn{1}{|c|}{ (Constant) } & Tolerance & VIF \\
\hline 1 & & \\
Ln_TOTAL_ASSET & .487 & 2.052 \\
Ln_PAD & .477 & 2.098 \\
PERTUMBUHAN_EKONOMI & .967 & 1.034 \\
\hline
\end{tabular}

a. Dependen Variabel : KELEMAHAN_SPI

Nilai VIF (Variance Inflation Factor) untuk varibel pertumbuhan ekonomi sebesar 1,034, variabel ukuran pemerintahan daerah sebesar 2,052 dan variabel pendapatan asli daerah sebesar 2,098, seluruhnya tidak ada yang bernilai lebih dari 10. Begitu juga dengan nilai Tolerance untuk variabel pertumbuhan ekonomi sebesar 0,967, variabel ukuran pemerintahan daerah sebesar 0,487 dan variabel pendapatan asli daerah sebesar 0,477, tidak ada variabel yang bernilai kurang dari 0,1. Untuk itu maka dapat disimpulkan bahwa tidak terdapat gejala multikolinieritas pada variabel-variabel penelitian ini.

\section{Hasil Uji Hipotesis Penelitian}

\section{Hasil Uji Koefisien Determinasi $\left(\mathbf{R}^{2}\right)$}

Pada model regresi berganda penggunaan adjusted $R^{2}\left(\operatorname{Adj} R^{2}\right)$, atau koefisien determinasi yang telah disesuaikan lebih baik dalam melihat seberapa jauh kemampuan model dalam menerangkan variasi variabel dependen bila dibandingkan dengan $\mathrm{R}^{2}$. Di bawah ini disajikan hasil uji Adj $\mathrm{R}^{2}$ penelitian sebagaimana tabel 4.4 sebagai berikut:

\section{Tabel 4.4}

\section{Hasil Uji Koefisien Determinasi}

\begin{tabular}{|c|c|c|c|c|}
\hline Model & $\mathrm{R}$ & R Square & Adjusted R Square & Std. Error of the Estimate \\
\hline 1 & $.655^{\mathrm{a}}$ & .429 & .409 & 1.72933 \\
\hline
\end{tabular}

b. Dependent Variable: KELEMAHAN_SPI

Dari Tabel 4.4 di atas, diperoleh nilai Koefisien Determinasi atau Adjusted R Square sebesar 0,409. Hal ini berarti bahwa 40,9\% variasi naik turunnya jumlah temuan kelemahan pengendalian intern pemerintah kabupaten/kota di Indonesia di dijelaskan oleh variabel pertumbuhan ekonomi, ukuran pemerintah daerah dan pendapatan asli daerah. Sedangkan sisanya sebesar $59,1 \%$ dijelaskan oleh variabel lain yang tidak dimasukkan dalam penelitian ini.

\section{Uji Signifikansi Simultan (Uji F)}

Uji statistik F atau uji ANOVA bertujuan untuk mengetahui apakah seluruh variabel independen secara bersama-sama (simultan) memiliki pengaruh yang signifikan terhadap variabel dependen. Hasil uji statistik F dapat dilihat pada tabel 4.5 sebagai berikut: 


\section{JMM JUPNAL UNRAM VOL. 6 No. 1 MARET 2017}

Tabel 4.5

Hasil Uji Statistik F

ANOVA $^{b}$

\begin{tabular}{|c|c|c|c|c|c|c|}
\hline \multicolumn{2}{|c|}{ Model } & Sum of Squares & $\mathrm{df}$ & Mean Square & $\mathrm{F}$ & Sig. \\
\hline 1 & Regression & 232.436 & 3 & 77.479 & 5.121 & $.002^{\mathrm{a}}$ \\
\hline & Residual & 2178.611 & 143 & 15.129 & & \\
\hline & Total & 2411.047 & 146 & & & \\
\hline
\end{tabular}

a. Predictors: (Constant), PERTUMBUHAN_EKONOMI, Ln_TOTAL_ASSET, Ln_PAD

b. Dependent Variable: KELEMAHAN_SPI

Tabel 4.5 menunjukkan bahwa nilai $\mathrm{F}$ hitung sebesar 5,121 dengan probabilitas 0,002. Karena probabilitas $\mathrm{F}$ hitung sebesar 0,002 lebih kecil dari $a=0,05$, dan nilai $\mathrm{F}$ hitung sebesar 5,121 lebih besar dari nilai $\mathrm{F}$ tabel sebesar 2,43 maka hipotesis nol $\left(\mathrm{H}_{0} 4\right)$ yang menyatakan bahwa tidak terdapat pengaruh simultan pertumbuhan ekonomi, ukuran pemerintah daerah dan pendapatan asli daerah terhadap kelemahan sistem pengendalian intern ditolak, dan sebaliknya hipotesis alternatif (Ha4) yang menyatakan pertumbuhan ekonomi, ukuran pemerintah daerah dan pendapatan asli daerah secara simultan berpengaruh terhadap kelemahan sistem pengendalian intern diterima.

Hasil Uji Signifikansi Paramater Individual (Uji t)

Uji t bertujuan untuk mengetahui seberapa jauh pengaruh variabel independen secara individual (parsial) yaitu rasio pertumbuhan ekonomi(GROWTH) Pendapatan Asli Daerah (PAD) dan Kompleksitas Pemerintah Daerah yang dilihat dari jumlah Total Aset Daerah dalam menerangkan variabel dependen yaitu kelemahan pengendalian intern (ICW). Signifikansi model regresi pada penelitian ini diuji dengan melihat nilai sig. yang ada di tabel 4.6 sebagai berikut:

Tabel 4.6

Hasil Uji Signifikansi Paramater Individual (Uji Statistik t)

Coefficients

\begin{tabular}{|c|c|c|c|c|c|c|}
\hline \multirow{2}{*}{\multicolumn{2}{|c|}{ Model }} & \multicolumn{2}{|c|}{ Unstandardized Coefficients } & \multirow{2}{*}{$\begin{array}{c}\begin{array}{c}\text { Standardized } \\
\text { Coefficients }\end{array} \\
\text { Beta }\end{array}$} & \multirow{2}{*}{$\mathrm{T}$} & \multirow[b]{2}{*}{ Sig. } \\
\hline & & B & Std. Error & & & \\
\hline \multirow[t]{4}{*}{1} & (Constant) & 9,768 & 12,769 & & 2.518 & .013 \\
\hline & Ln_TOTAL_ASSET & -2.001 & 1.013 & -.224 & -1.977 & .050 \\
\hline & Ln_PAD & .342 & .540 & .073 & .633 & .528 \\
\hline & PERTUMBUHAN_EKONOMI & .911 & .288 & .255 & 3.167 & .002 \\
\hline
\end{tabular}

a. Dependent Variable: KELEMAHAN_SPI

Berdasarkan Tabel 4.6 diatas diperoleh nilai t hitung dan signifikansi masing-masing variabel independen, yaitu: $t=3,167$ dan Sig. $=0,002$ untuk variabel pertumbuhan ekonomi; $\mathrm{t}=-1,977$ dan Sig. $=0,050$ untuk variabel ukuran daerah yang diproksikan dengan logaritma natural total asset; dan $\mathrm{t}=0,633$ dan Sig. $=0,528$ untuk variabel pendapatan asli daerah.

Pada variabel pertumbuhan ekonomi, nilai signifikansi sebesar 0,002 adalah lebih kecil dari nilai $\mathrm{a}=0,05$ dan nilai $\mathrm{t}$ hitung sebesar 3,617 adalah lebih besar dari nilai $\mathrm{t}$ tabel sebesar $1,65536\left(\mathrm{t}_{(0,05 .}\right.$ 146) $\left._{1}=1,65536\right)$. Oleh karena itu hipotesis nol $\left(\mathrm{H}_{0} 1\right)$ yang menyatakan bahwa tidak terdapat pengaruh pertumbuhan ekonomi terhadap kelemahan sistem pengendalian intern ditolak. Sebaliknya hipotesis alternatif (Ha1) yang menyatakan bahwa pertumbuhan ekonomi berpengaruh terhadap kelemahan sistem pengendalian intern diterima.

Pada variabel ukuran pemerintah daerah, nilai signifikansi sebesar 0,050 adalah sama dengan nilai $a=0,05$ dan nilai thitung sebesar $-1,977$ (dengan mengabaikan tanda negatif) 


\section{JURNAL MAGISTER MANAJEMEN
UNIVERSITAS MATARAM UNRAM VOL. 6 No. 1 MARET 2017}

adalah lebih besar dari nilai $\mathrm{t}$ tabel sebesar 1,65536 $\left(\mathrm{t}\left(0,05\right.\right.$. $\left._{146)}=1,65536\right)$. Oleh karena itu hipotesis nol $\left(\mathrm{H}_{0} 2\right)$ yang menyatakan bahwa tidak terdapat pengaruh ukuran pemerintah daerah terhadap kelemahan sistem pengendalian intern ditolak. Sebaliknya hipotesis alternatif (Ha2) yang menyatakan bahwa ukuran pemerintah daerah berpengaruh terhadap kelemahan sistem pengendalian intern diterima.

Untuk variabel pendapatan asli daerah, nilai signifikansi sebesar 0,528 adalah lebih besar dari nilai $a=0,05$ dan nilai $t$ hitung sebesar 0,633 adalah lebih kecil dari nilai $t$ tabel sebesar $1,65536(t)(0,05.146)=1,65536)$. Oleh karena itu hipotesis nol $\left(\mathrm{H}_{0} 3\right)$ yang menyatakan bahwa tidak terdapat pengaruh pendapatan asli daerah terhadap kelemahan sistem pengendalian intern diterima. Sebaliknya hipotesis alternatif (Ha3) yang menyatakan bahwa pendapatan asli daerah berpengaruh terhadap kelemahan sistem pengendalian intern ditolak.

Selanjutnya pada Tabel 4.6 di atas juga diperoleh nilai konstanta sebesar 9,768, koefisien regresi variabel pertumbuhan ekonomi sebesar 0,911, koefisien regresi variabel ukuran daerah sebesar -2,001 dan koefisien regresi pendapatan asli daerah sebesar 0,342. Sehingga dapat dibangun sebuah model regresi sebagai berikut:

dimana:

KSPI = 9,768 + 0,911PE - 2.001UPD + 0,342PAD

KSPI $=$ Kelemahan Sistem Pengendalian Intern

$\mathrm{PE} \quad=$ Pertumbuhan Ekonomi

UPD = Ukuran Pemerintah Daerah yang dinyatakan dalam logaritma natural Total Asset

PAD = Pendapatan Asli Daerah yang dinyatakan dalam logaritma natural PAD.

Berdasarkan model persamaan regresi di atas, dapat dijelaskan sebagai berikut: 1) nilai konstanta sebesar 9,768 menunjukkan bahwa kelemahan sistem pengendalian intern akan bernilai 9,768 (atau 10 temuan) walaupun tidak ada variasi naik turunnya nilai variabel pertumbuhan ekonomi, total asset dan pendapatan asli daerah; 2) nilai koefisien regresi variabel pertumbuhan ekonomi sebesar $+0,911$ memberikan makna bahwa setiap variasi naik atau turunnya nilai variabel pertumbuhan ekonomi sebesar 1 satuan memberikan pengaruh positif (searah) terhadap variasi naik turunnya nilai kelemahan sistem pengendalian intern sebesar 0,911 temuan, dengan asumsi variabel lain konstan; 3) nilai koefisien regresi variabel ukuran pemerintah daerah sebesar -2,001 memberikan makna bahwa setiap variasi naik turunnya nilai variabel ukuran daerah yang dinyatakan dalam logaritma natural total asset sebesar 1 satuan memberikan pengaruh negatif (berlawanan arah) terhadap variasi naik turunnya nilai kelemahan sistem pengendalian intern sebesar 2,001 temuan, dengan asumsi variabel lain konstan; dan 4) nilai koefisien regresi variabel pendapatan asli daerah sebesar $+0,342$ memberikan makna bahwa setiap variasi naik turunnya nilai variabel pendapatan asli daerah yang dinyatakan dengan logaritma natural pendapatan asli daerah sebesar 1 satuan memberikan pengaruh positif (searah) terhadap variasi naik turunnya nilai kelemahan sistem pengendalian intern sebesar 0,342 temuan dengan asumsi variabel lain konstan.

\section{Pembahasan}

Sistem pengendalian intern, berdasarkan PP Nomor 60 tahun 2008, adalah proses yang integral pada tindakan dan kegiatan yang dilakukan secara terus menerus oleh pimpinan dan seluruh pegawai untuk memberikan keyakinan memadai atas tercapainya tujuan organisasi melalui kegiatan yang efektif dan efisien, keandalan pelaporan keuangan, pengamanan aset negara, dan ketaatan terhadap peraturan perundang-undangan. 


\section{IMM JURNAL MAGISTER MANAJEMEN UNIVERSITAS MATARAM UNRAM VOL. 6 No. 1 MARET 2017}

Berdasarkan peraturan pemerintah tersebut, menjadi sebuah kewajiban bagi setiap entitas akuntansi dan pelaporan termasuk pemerintah daerah kabupaten/kota untuk mengimplementasikan praktik-praktik sistem pengendalian intern yang baik sehingga dapat memberikan keyakinan memadai atas tercapainya tujuan organisasi melalui kegiatan yang efektif dan efisien, keandalan pelaporan keuangan, pengamanan aset negara, dan ketaatan terhadap peraturan perundang-undangan.

Untuk menilai implementasi sistem pengendalian intern pada pemerintah daerah kabupaten/kota di Indonesia, BPK melakukan penilaian SPI yang terintegrasi dalam Pemeriksaan Laporan Keuangan Pemerintah Daerah, yang hasilnya dapat dilihat dalam Indeks Hasil Pemeriksaan berupa data jumlah temuan terkait kelemahan sistem pengendalian intern. Banyak faktor yang mungkin dapat mempengaruhi tingkat implementasi sistem pengendalian intern pada pemerintah daerah, tetapi di dalam penelitian ini khusus mendalami pengaruh faktor pertumbuhan ekonomi, ukuran pemerintah daerah dan pendapatan asli daerah terhadap kelemahan sistem pengendalian intern.

\section{Pengaruh Pertumbuhan Ekonomi terhadap Kelemahan Sistem Sistem Pengendalian Intern}

Pertumbuhan ekonomi merupakan salah satu tujuan penting dalam gerakan pembangunan yang dicanangkan pemerintah. Keberhasilan atau kegagalan suatu pemerintahan seringkali dikaitkan dengan pertumbuhan ekonomi yang pernah dicapai pada masanya. Untuk mencapai pertumbuhan ekonomi yang baik, aktivitas sektor-sektor ekonomi digerakkan, dan pemerintah memiliki peran penting dalam menggerakkan sektorsektor ekonomi berdasarkan potensi yang ada melalui perencanaan yang baik, penetapan kebijakan dan pengalokasian belanja yang tepat serta pengawasan yang efektif.

Kompleksnya aktifitas pemerintahan dalam menggerakkan ekonomi untuk mencapai pertumbuhan ekonomi yang lebih baik tentu membutuhkan aktifitas pengendalian yang kompleks pula. Hal ini tentu akan membuka peluang munculnya temuan-temuan terkait kelemahan sistem pengendalian intern.

Untuk membuktikan munculnya temuan-temuan terkait kelemahan sistem pengendalian intern berkaitan dengan aktifitas pemerintahan dalam menggerakkan ekonomi untuk mencapai pertumbuhan ekonomi yang lebih baik, dalam peneltian ini sebagaimana diuraikan dalam hasil uji signifikansi parameter individual (uji statistik $\mathfrak{t}$ ) di atas, disimpulkan bahwa hipotesis nol $\left(\mathrm{H}_{0} 1\right)$ yang menyatakan tidak terdapat pengaruh pertumbuhan ekonomi terhadap kelemahan sistem pengendalian intern ditolak dan sebaliknya hipotesis alternatif (Ha1) yang menyatakan pertumbuhan ekonomi berpengaruh terhadap kelemahan sistem pengendalian intern diterima. Selanjutnya dengan melihat koefisien regresi variabel pertumbuhan ekonomi sebesar 0,911 bertanda positif, maka dapat dinyatakan bahwa pertumbuhan ekonomi berpengaruh positif terhadap kelemahan sistem pengendalian intern. Hal ini berarti semakin baik tingkat pertumbuhan ekonomi suatu daerah akan semakin membuka peluang meningkatnya jumlah temuan terkait kelemahan sistem pengendalian intern.

Pernyataan ini sejalan dengan hasil penelitian Martani dan Zaelani (2011) dengan mengambil sampel 229 pemerintah kabupaten/kota tahun 2008 dimana pertumbuhan memiliki pengaruh signifikan positif terhadap tingkat kelemahan pengendalian intern. Hasil penelitian ini juga sejalan dengan hasil penelitian Doyle et al. (2007), dan Petrovits et al. (2010), walaupun obyek dari kedua penelitian ini berbeda. Doyle et al. (2007), dengan menjadikan sampel sebanyak 779 perusahaan yang mengungkap kelemahan pengendalian intern dalam pelaporan keuangan berdasarkan Sarbanas-Oxley Ac (SOX) seksi 302 dan seksi 


\section{JURNAL MAGISTER MANAJEMEN
UNIVERSITAS MATARAM UNRAM VOL. 6 No. 1 MARET 2017}

404 dari bulan agustus 2002 sampai 2005 diantaranya menemukan bahwa perusahaan yang memiliki banyak kelemahan pengendalian intern cenderung pada perusahaan yang sedang tumbuh. Petrovits et al. (2010) yang meneliti menggunakan sampel sebanyak 27.495 lembaga amal (organisasi nirlaba) tahun 1999 sampai 2007 menyimpulkan bahwa masalah pengendalian intern berhubungan positif dengan kondisi organisasi yang sedang tumbuh.

Pengaruh Ukuran Pemerintah Daerah terhadap Kelemahan Sistem Pengendalian Intern.

Ukuran suatu pemerintah daerah dapat menggambarkan besar kecilnya skala aktivitas yang ada di dalamnya. Ukuran pemerintah daerah dapat dilihat dari besar kecilnya total asset yang dikelola oleh pemerintah daerah yang bersangkutan. Pemerintah daerah yang mengelola aset dalam jumlah yang besar tentu memiliki resiko yang tinggi untuk terjadinya penggelapan atau tindak penyalahgunaan aset pemerintah. Oleh karena tingginya resiko ini, maka pengelolaan aset biasanya mendapat tekanan atau perhatian lebih dari pemangku kebijakan beserta stakeholder pemerintah daerah untuk menjaga keutuhan aset-aset yang ada. Untuk menjaga keutuhan aset-aset pemerintah daerah, tentu dilakukan dengan penerapan sistem pengendalian intern yang baik. Dengan diterapkan sistem pengendalian intern yang baik dalam pengelolaan aset pemerintah daerah pada akhirnya akan mengurangi potensi munculnya temuan terkait kelemahan pengendalian intern.

Untuk membuktikan munculnya temuan-temuan terkait kelemahan sistem pengendalian intern berkaitan dengan ukuran pemerintah yang proksikan dengan nilai total asset, dalam peneltian ini sebagaimana diuraikan dalam hasil uji signifikansi parameter individual (uji statistik $\mathrm{t}$ ) di atas, disimpulkan bahwa hipotesis nol $\left(\mathrm{H}_{0} 2\right)$ yang menyatakan bahwa tidak terdapat pengaruh ukuran pemerintah daerah terhadap kelemahan sistem pengendalian intern ditolak. Sebaliknya hipotesis alternatif (Ha2) yang menyatakan bahwa ukuran pemerintah daerah berpengaruh terhadap kelemahan sistem pengendalian intern diterima. Selanjutnya dengan melihat koefisien regresi variabel ukuran pemerintah daerah sebesar -2.001 bertanda negatif, maka dapat dinyatakan bahwa ukuran pemerintah daerah berpengaruh negatif terhadap kelemahan sistem pengendalian intern. Hal ini berarti semakin besar ukuran pemerintah daerah dilihat dari nilai total assetnya semakin baik kualitas sistem pengendalian internnya, dan sebaliknya semakin kecil ukuran pemerintah daerah dilihat dari total assetnya semakin lemah sistem pengendalian internnya.

Hasil penelitian ini sejalan dengan hasil penelitian Petrovits et al. (2010) yang menyatakan bahwa masalah pengendalian intern pada organisasi nirlaba memiliki hubungan posistif dengan kondisi organisasi yang berukuran kecil. Hasil penelitian ini juga searah dengan hasil penelitian Zhang et al. (2009) yang menemukan bahwa kualitas pengendalian intern berhubungan positif dengan ukuran perusahaan yang diukur dengan data total aset perusahaan.

Pengaruh Pendapatan Asli Daerah terhadap Kelemahan Sistem Pengendalian Intern.

Untuk membuktikan munculnya temuan-temuan terkait kelemahan sistem pengendalian intern berkaitan dengan pendapatan asli daerah, dalam peneltian ini sebagaimana diuraikan dalam hasil uji signifikansi parameter individual (uji statistik t) di atas, disimpulkan bahwa hipotesis nol $\left(\mathrm{H}_{0} 3\right)$ yang menyatakan bahwa tidak terdapat pengaruh pendapatan asli daerah terhadap kelemahan sistem pengendalian intern diterima. Sebaliknya hipotesis alternatif (Ha3) yang menyatakan bahwa pendapatan asli daerah berpengaruh terhadap kelemahan sistem pengendalian intern ditolak, maka dapat disimpulkan bahwa pendapatan asli daerah tidak berpengaruh signifikan terhadap kelemahan sistem pengendalian intern. Tetapi dengan melihat koefisien regresi variabel pendapatan asli daerah sebesar 0,342 bertanda positif, maka dapat dinyatakan bahwa walaupun tidak signifikan, ukuran pemerintah daerah dapat memberikan berpengaruh 


\section{JURNAL MAGISTER MANAJEMEN
UNIVERSITAS MATARAM UNRAM VOL. 6 No. 1 MARET 2017}

positif terhadap kelemahan sistem pengendalian intern. Hal ini berarti semakin besar nilai pendapatan asli daerah, semakin berkurang jumlah temuan terkait kelemahan sistem pengendalian intern walaupun dalam jumlah yang tidak signifikan.

Hasil penelitian ini sejalan dengan hasil penelitian Hartono dkk. (2014) dengan mengambil sampel 33 pemerintah provinsi tahun 2011 yang menyatakan pendapatan asli daerah tidak berpengaruh signifikan terhadap kelemahan pengendalian intern.

Pengaruh Simultan Pertumbuhan Ekonomi, Ukuran Pemerintah Daerah, dan Pendapatan Asli Daerah Terhadap Kelemahan Sistem Pengendalian Intern.

Pada intinya pengujian simultan beberapa variabel independen terhadap variabel dependen menggunakan statistik $\mathrm{F}$ adalah untuk memberikan gambaran kelayakan model regresi yang dihasilkan. Nilai probabilita F hitung yang mendekati nol menujukkan model regresi yang dihasilkan dengan melibatkan beberapa variabel independen sangat layak untuk memprediksi variasi nilai variabel dependen.

Pada hasil pengujian statistik $\mathrm{F}$ sebagaimana Tabel 4.7 diatas, menunjukkan bahwa probabilita F hitung sebesar 0,002 lebih kecil dari $a=0,05$, dan nilai F hitung sebesar 5,121 lebih besar dari nilai $\mathrm{F}$ tabel sebesar 2,43 maka hipotesis nol $\left(\mathrm{H}_{0} 4\right)$ yang menyatakan bahwa tidak terdapat pengaruh simultan pertumbuhan ekonomi, ukuran pemerintah daerah dan pendapatan asli daerah terhadap kelemahan sistem pengendalian intern ditolak, dan sebaliknya hipotesis alternatif (Ha4) yang menyatakan pertumbuhan ekonomi, ukuran pemerintah daerah dan pendapatan asli daerah secara simultan berpengaruh terhadap kelemahan sistem pengendalian intern diterima. Ini berarti bahwa konstruksi model regresi linier yang terbentuk dengan melibatkan variabel pertumbuhan ekonomi, ukuran pemerintah daerah dan pendapatan asli daerah sangat layak untuk memprediksi variasi nilai variabel kelemahan sistem pengendalian intern.

Selanjutnya, dengan melihat nilai Koefisien Determinasi atau Adjusted $R$ Square sebesar 0,409, ini berarti bahwa variasi naik turunnya jumlah temuan kelemahan sistem pengendalian intern pemerintah kabupaten/kota di Indonesia di dijelaskan sebesar 40,90\% oleh variabel pertumbuhan ekonomi, ukuran pemerintah daerah dan pendapatan asli daerah. Sedangkan sisanya sebesar $59,10 \%$ dijelaskan oleh variabel lain yang tidak dimasukkan dalam penelitian ini.

\section{PENUTUP}

\section{Kesimpulan}

Penelitian ini bertujuan untuk mengetahui apakah pertumbuhan ekonomi, pendapatan asli daerah dan ukuran pemerintah daerah berpengaruh terhadap kelemahan sistem pengendalian intern. Dengan mengambil sampel data sebanyak 146 pemerintah daerah kabupaten dan kota di Indonesia tahun 2013, hasil penelitian ini menyimpulkan bahwa:

1. Pertumbuhan ekonomi, ukuran pemerintah daerah yang diproksikan dengan total aset, dan pendapatan asli daerah secara simultan berpengaruh signifikan terhadap kelemahan sistem pengendalian intern pemerintah daerah.

2. Pertumbuhan ekonomi secara parsial berpengaruh positif terhadap kelemahan sistem pengendalian intern.

3. Ukuran pemerintah daerah yang diproksikan dengan total asset secara parsial berpengaruh negatif terhadap kelemahan sistem pengendaian intern.

4. Pendapatan asli daerah berpengaruh positif tetapi tidak signifikan terhadap kelemahan sistem pengendalian intern.. 


\section{JMM JUPNAL UNRAM VOL. 6 No. 1 MARET 2017}

\section{DAFTAR PUSTAKA}

Arens, Alvin A., Elder, Randel J.,Beasley, Mark S. 2003. Auditing and Asurance Services, An Integrated Approach. Ninth Edition. Pearson Education International New Jersey.

Ashbaugh-Skaife, H., Collins, Daniel W., dan Kinney, William R. 2006. The Discovery and Reporting of Internal Control Deficiencies Prior to SOX-Mandated Audits.McCombs Research Paper Series No.ACC-02-05.

Badan Pemeriksa Keuangan. 2007. Peraturan BPK RI Nomor 1 Tahun 2007 tentang Standar Pemeriksaan Keuangan Negara : http://www.bpk.go.id diakses pada 25 November 2015.

2013. Ikhtisar Hasil Pemeriksaan Semester I Tahun 2013 : http://www.bpk.go.id diakses pada 25 November 2015

2013. Ikhtisar Hasil Pemeriksaan Semester II Tahun 2013: http://www.bpk.go.id diakses pada 25 November 2015

2014. Ikhtisar Hasil Pemeriksaan Semester I Tahun 2014: http://www.bpk.go.id diakses pada 25 November 2015

2014. Ikhtisar Hasil Pemeriksaan Semester II Tahun 2014: http://www.bpk.go.id diakses pada 25 November 2015

Blakely, Edward J. 1994. Planing Local Economic Development Theory and Practice. Second Edition. USA, Sage Publication.

Budiono, 1985. Pengantar Ilmu Ekonomi No. 4. BPFE. Yogyakarta.

Colombatto, Enrico. 2001. Discreationary power, rent-seeking and corruption. University di Torino E ICER, working paper.

Commitee of Sponsoring Organization (COSO) of The Treadway Commission. http://www.soxonline.com

Doyle, J., Ge, Weili, McVay, Sarah. 2007. Determinants of Weaknesses in Internal Control Over Financial Reporting. Journal of Accounting and Economics, 44: 193-223.

Elgie, Robert \& Erik Jones.2000. Agents, Principals and the Study of Institutions: Constructing a Principal-Centered Account of Delegation. Working documents in the Study of European Governace Number: 5. Center for the Study of European Governance (CSEG)

Fama dan Jensen. 1983. The Separation of Ownership and Control. Journal of Law and Economics, $26, p p$.

Ge, Weili, McVay, Sarah. 2005. The Disclosure of Material Weaknesses in Internal Controlafter The Sarbanas-Oxley Act. Accounting Horizon, 19 (3):137-158.

Ghozali, Imam dan Anis Chariri. 2003. Teori Akuntansi. Badan Penerbit Universitas Diponegoro. Semarang.

Ghozali, Imam. 2013. Aplikasi Analisis Multivariat dengan Program IBM SPSS, BP UNDIP. Semarang.

Halim, Abdul \& Syukriy Abdullah. 2004. Pengaruh Dana Alokasi Umum dan Pendapatan Asli Daerah Terhadap Belanja Pemda: Studi Kasus Kabupaten dan Kota di Jawa dan Bali. Jurnal Ekonomi STEI No.2/Tahun XIII/ 25.

2006. Hubungan dan Masalah Keagenan di Pemerintahan Daerah: Sebuah Peluang Penelitian Anggaran dan Akuntansi.

Hartono, Rudi, Amir Mahmud, dan Nanik Sri Utaminingsih.2014.Faktor-Faktor Yang Mempengaruhi Kelemahan Pengendalian Intern Pemerintah Daerah. Proceding Seminar Nasional Akuntansi XVII Mataram

Holmes, Arthur W. And Burns David C. 1990. Auditing Standar and Procedures. Ninth Edition. Dialihbahasakan oleh Marianus Sinaga. Erlangga. Jakarta. 1998. 


\section{TMM JURNAL MAGISTER MANAJEMEN UNIVERSITAS MATARAM UNRAM VOL. 6 No. 1 MARET 2017}

Ibrahim, Hadiasman. 2008. Pengaruh Tingkat Suku Bunga, Peringkat Obligasi, Ukuran Perusahaan dan DER Terhadap Yield to Maturity Obligasi Korporasi di Bursa Efek Indonesia Periode Tahun 2004-2006. Tesis. Program Studi Magister Manajemen Program Pasca Sarjana Universitas Diponegoro, Semarang.

Indriani, Yeni. 2005. Analisis Faktor Ekonomi Terhadap Investasi PMDN di Propinsi Bengkulu. Jurnal Ekonomi FE-UNIB. Vol. XV No.02

Jensen,M.C. and W.H. Meckling. Theory of The Firm: Managerial Behavior, Agency Cost and Ounership Structure. Jurnal of Financial Economoc. (Oktober 1976)

Johnson, Cathy Marie. 1994. The Dyinamics of Conflict Between Bureaucrats and Legislators. Armonk, New York: M.E.Sharpe

Kasper, Wolfang \& Manfred E Streit.2001. Institutional Economics:Social Order and Public Policy.Cheltham, UK:Edward Elgar.

KPMG. 2013. A survey of fraud, bribery and corruption in Australia ENew Zealand 2012. kpmg.com.au, kpmg.co.nz.

Komala, Siti, Gde Adi Yuniarta dan I Made Pradana Adiputra. Analisis Perbedaan Ukuran Koperasi dan Jenis Koperasi Terhadap Kualitas Sistem Pengendalian Intern (Studi Kasus Pada Koperasidi Kabupaten Buleleng). e-Journal Ak Universitas Pendidikan Ganesha. Volume 2 No: 1 Tahun 2014.

Kristanto, Septian Bayu. 2009. Pengaruh Ukuran Pemerintahan, Pendapatan Asli daerah (PAD), dan Belanja Modal Sebagai Prediktor Kelemahan Pengendalian Internal. Jurnal Akuntansi UKRIDA, Volume 9, No.1, Januari 2009-ISSN:1411-691X

Latifah, Nurul P. 2010. Adakah perilaku oportunistik dalam aplikasi agency theory di sektor publik? Fokus Ekonomi, Vol 5 No.2.

Machfoed, Mas'ud. 1994. Financial Ratio Analysis and The Prediction Of Earning Changes in Indonesia. Kelola. Vol.3, No.7.

Mardiasmo. 2002. Otonomi dan Manajemen Keuangan Daerah. Andi. Yogyakarta.

Martani, Dwi dan Fazri Zaelani. 2011. Pengaruh Ukuran, Pertumbuhan, dan Kompleksitas Terhadap Pengendalian Intern Pemerintah daerah Studi Kasus di Indonesia. Simposium Nasional Akuntansi XIV Aceh 2011.

Mulyadi, 2001, Sistem Akuntansi. Salemba Empat, Jakarta.

Nirmala, Swastia dan Daljono. 2013. Analisis Pengaruh Profitabilitas, Ukuran Perusahaan, Laju Pertumbuhan, dan Kompleksitas Transaski Terhadap Kelemahan Pengendalian Internal. Diponegoro Journal Of Accounting. Volume 2, Nomor 1, Tahun 2013, Hal.1-9.

Nugroho, Bhuono, Agung. 2005. Strategi Jitu Memilih Metode Statistik Penelitian Dengan SPSS, Edisi I. Andi. Yogyakarta.

Panjaitan, Yunia. 2004. Analisis Harga Saham, Ukuran Perusahaan, dan Resiko Terhadap Return Yang Diharapkan Investor Pada Perusahaan Saham Aktif. Balance Vol.1.

Petrie, Murray.2002. A Framework For Public Sector Performance Contracting. OECD Journal on Budgeting: 117-153

Petrovits, Christine, Shakespeare, Chatarine, dan Shih, Aime. 2010. The Chauses and Consequences of Internal Control Problems in Nonprofit Organizazions.

Republik Indonesia. Peraturan Pemerintan Republik Indonesia Nomor 60 Tahun 2008 tentang Sistem Pengendalian Intern Pemerintah. Departemen Komunikasi dan Informatika. Jakarta.

Samuelson, Paul. 2004. Ilmu Makro Ekonomi, Edisi 17 (terjemahan). Penerbit Media Global Edukasi. Jakarta.

Scot, Wiliam R. 1997. Financial Accounting Theory, Third Edition. 


\section{$J M M$

Sekaran, Uma. 2006. Research Methods For Business. United States : Willey.

Sigiyono. 2013. Metode Penelitian Kuantitatif, Kualitatif dan R\&D. Alfa Beta. Bandung.

Sutrisno. 2001. Manajemen Keuangan. Edisi 2. Ekonosia, Yogyakarta.

Wilkinson, W. Joseph, Michael J. Cerullo, Vasant Raval \& Bernard Wong-On-Wing.2000. Accounting Information Syistems: Essentials Concepts and Applications Fourth Edition. John Wiley and Sons.Inc.

Zhang, Ying, Dong Xiao Niu, and Hong Tao Zheng. (2009). Research on the determinants of the quality of internal control. Evidence from China. International Conference on Information Management, Innovation Management and Industrial Enginering Paper. 